\title{
Estimating production and utilization of jojoba
}

\author{
BRUCE A. ROUNDY, G.B. RUYLE, AND JANE ARD
}

Abstract

Jojoba (Simmondsia chinensis) is a major evergreen browse species for livestock and wildlife throughout its range from central Arizona to northweat Mexico and Baja California. Current guidelines for grazing management are based on utilization levels as estimated from determining the percentage of twigs grazed. Utillzation can be eatimated more accurately from twis diameter measurements. On 3 sites in southern Arizona, leaf weight, stem weight and total weight were correlated with the square of twig internode diameter, having average $r^{2}$ values of $0.81,0.73$, and 0.83 , respectively, for small diameter twigs ( $\leq 3 \mathrm{~mm}$ ) most frequently browsed. Estimates of twig weight from regression equations for the 3 sites varied leas than $0.3 \mathrm{~g}$ and low standard errors of eatimate $(\leq 0.33)$ indicate twig diameter measurements can give precise estimates of twis weight. Percent utilization of current year's growth can be calculated from estimates of twis weight remaining and twig weight removed by grazing from diameter measurements at initiation of current year's growth and at the point of graxing, respectively. On 2 sites, mean grazed twigs and mean weight utilization were similar for shrubs moderately grazed by cattle. However, regressions of weight utilization on percent twigs grazed indicated that percent twigs grazed could overestimate weight utilization of total twigs and underestimate weight utilization of current year's twigs, especially when utilization is high. An alternative to basing management of jojoba on time-consuming utilization measurements and arbitrary utilization limits is to monitor size of marked shrubs and manage for stable or gradually increasing shrub size.

Key Words: browsing, Sonoran Desert, shrubs, Stmunondsta chinensis

Jojoba (Simmondsia chinensis) is a drought-tolerant, long-lived evergreen shrub of the Sonoran desert in northwestern Mexico and the southwestern United States. It grows best on well-drained, well-aerated, coarse soils associated with desert foothills and

Authors are assistant professor, range management specialist and research assistant, School of Renewable Natural Resources, University of Arizona, Tucson 85721. Published as Arizona Agricultural Experiment Station Paper 5063.

Manuscript accepted 2 August 1988. washes from 600 to $1,200 \mathrm{~m}$ (Gentry 1958). The high content and desirable properties of wax esters in jojoba seed (Scarlett 1978) have led to extensive research on the chemistry, use, and cultivation of this desert shrub (Elias-Cesnik 1982). Jojoba is also the best browse species for wildlife and livestock within its range (Kearney and Peebles 1964). Jojoba has historically been used by goats, sheep and cattle and provides food for rodents and birds (Gentry 1958, Sherbrooke 1976, Thomson 1976, Martin et al. 1951), javelina (Pecari tajaco) (Knipe 1956), desert bighorn sheep (Ovis canadensis)(Russo 1956), and mule deer (Odocoileus hemionus)(Judd 1962, McCulloch and Urness 1973, Urness et al. 1977).

Management guidelines for use of jojoba are those followed for other shrubs (Garrison 1971), including limits of $40 \%$ utilization under continuous grazing and $50 \%$ utilization under a rest rotation grazing system (USDA Forest Service 1979). Utilization is generally estimated by determining the percentage of current year's twigs that have been browsed (USDA Forest Service 1979). This method may overestimate actual weight utilization, epecially where use is high (Stickney 1966, Jensen and Scotter 1977, Ruyle et al. 1983). A more accurate but more tedious method of estimating utilization is that of using least squares regression analysis to determine the relationship between twig weight and twig length or diameter (Rutherford 1979). Diameters of length of browsed and unbrowsed current year's twigs can than be measured to estimate the weight left and weight removed to calculate utilization. The purpose of this research was to examine methods of estimating jojoba utilization. Specific objectives were to compare the relationship of stem diameter to twig weight of jojoba growing on different sites and to determine the relationship of percent browsed twigs to percent weight removed by grazing.

\section{Methods}

Three sites were selected for initial jojoba sampling to develop diameter-weight relationships for jojoba. The sites were located on the eastern slope of the Tucson Mountains, the southern foothills of the Santa Catalina Mountains, and in the area of the 
Table 1. Intercepts(a), regresaion coeficiente(b), coefificients of determination ( $r^{2}$ ), and standard errors of estimate (S.E.E.) for jojoba twigs on 3 sites in southern Arizona of the form: $y=a+b x^{2}$, where $y$ is oven-dried welght(g) and $x$ is oven-dried mid-internode stem diameter (mm).

\begin{tabular}{|c|c|c|c|c|c|c|c|c|c|c|c|c|c|}
\hline \multirow[b]{2}{*}{ Site } & \multirow{2}{*}{$\begin{array}{c}\text { Number } \\
\text { observations }\end{array}$} & \multicolumn{4}{|c|}{ Leaf weight } & \multicolumn{4}{|c|}{ Stem weight } & \multicolumn{4}{|c|}{ Total weight } \\
\hline & & $a^{*}$ & $b^{*}$ & $r^{2}$ & $\overline{\text { S.E.E. }}$ & a & b & $r^{2}$ & S.E.E. & a & b & $r^{2}$ & S.E.E. \\
\hline $\begin{array}{l}\text { Roosevelt } \\
\text { Tucson } \\
\text { Santa Catalina } \\
\text { Sites combined }\end{array}$ & $\begin{array}{l}180 \\
162 \\
178 \\
510\end{array}$ & $\begin{array}{l}-0.42 b \\
-0.47 a \\
-0.28 a \\
-0.43\end{array}$ & $\begin{array}{c}0.48 a \\
0.42 b \\
0.34 c \\
0.42\end{array}$ & $\begin{array}{l}0.85 \\
0.90 \\
0.85 \\
0.85\end{array}$ & $\begin{array}{l}\text { S } \\
0.84 \\
0.61 \\
0.63 \\
0.75\end{array}$ & $\begin{array}{c}\text { em diam } \\
-0.29 a \\
-0.36 b \\
-0.30 b \\
-0.33\end{array}$ & $\begin{array}{l}\text { ter } \leq 5 \\
0.25 \mathrm{a} \\
0.24 \mathrm{a} \\
0.21 \mathrm{~b} \\
0.24\end{array}$ & $\begin{array}{l}\mathrm{am} \\
0.91 \\
0.92 \\
0.92 \\
0.91\end{array}$ & $\begin{array}{l}0.34 \\
0.31 \\
0.28 \\
0.31\end{array}$ & $\begin{array}{l}-0.72 b \\
-0.83 a \\
-0.59 a \\
-0.75\end{array}$ & $\begin{array}{l}0.72 \mathrm{a} \\
0.66 \mathrm{~b} \\
0.55 \mathrm{c} \\
0.66\end{array}$ & $\begin{array}{l}0.89 \\
0.92 \\
0.90 \\
0.89\end{array}$ & $\begin{array}{l}1.09 \\
0.88 \\
0.82 \\
0.99\end{array}$ \\
\hline $\begin{array}{l}\text { Roosevelt } \\
\text { Tucson } \\
\text { Santa Catalina } \\
\text { Sites combined }\end{array}$ & $\begin{array}{l}153 \\
141 \\
157 \\
451\end{array}$ & $\begin{array}{l}-0.12 b \\
-0.08 \mathrm{a} \\
-0.20 \mathrm{a} \\
-0.12\end{array}$ & $\begin{array}{l}0.30 \mathrm{a} \\
0.24 \mathrm{~b} \\
0.28 \mathrm{a} \\
0.27\end{array}$ & $\begin{array}{l}0.82 \\
0.84 \\
0.83 \\
0.81\end{array}$ & $\begin{array}{l}\text { St } \\
0.19 \\
0.20 \\
0.25 \\
0.22\end{array}$ & $\begin{array}{c}\text { em diam } \\
-0.07 a \\
-0.12 a \\
-0.13 a \\
-0.10\end{array}$ & $\begin{array}{l}\text { ter } \leq 3 \\
0.12 \mathrm{a} \\
0.13 \mathrm{a} \\
0.13 \mathrm{a} \\
0.13\end{array}$ & $\begin{array}{l}\text { Im } \\
0.56 \\
0.73 \\
0.82 \\
0.73\end{array}$ & $\begin{array}{l}0.14 \\
0.14 \\
0.12 \\
0.14\end{array}$ & $\begin{array}{l}-0.17 a \\
-0.20 b \\
-0.32 b \\
-0.22\end{array}$ & $\begin{array}{l}0.41 \mathrm{a} \\
0.37 \mathrm{a} \\
0.41 \mathrm{a} \\
0.39\end{array}$ & $\begin{array}{l}0.81 \\
0.83 \\
0.85 \\
0.83\end{array}$ & $\begin{array}{l}0.27 \\
0.32 \\
0.33 \\
0.31\end{array}$ \\
\hline
\end{tabular}

-Intercepts and regression coefficients for different sites followed by the same letter are not significantly different ( $p \leq 0.05$ ) according to the elevation and slope tests of Snedecor and Cochran (1971).

Horrell exclosure on the northern foothills of Two Bar Mountain south of Roosevelt Lake, all in southern Arizona. Associated soils are gravelly clay loams and principal vegetation includes Franseria dumosa, Larrea tridentata and Acacia constricta at the Tucson and Santa Catalina sites, Encilia farinosa at the Santa Catalina site, and Cercidium microphyllum, Lycium pallidum, and Larrea tridentata at the Roosevelt site in addition to jojoba.

During the summer of 1984, branches were sampled from 20 ungrazed shrubs at each of the 3 sites. To determine the relationship between fresh and oven-dried twig diameter, the midinternode diameter of 150 twigs ranging in water content from 9 to $52 \%$ was measured before and after drying in an oven at $70^{\circ} \mathrm{C}$ for 24 hours. Thereafter, all samples were oven-dried and minimum mid-internode diameter and leaf, stem, and total weight measured. Measurements for branches from each site included a minimum of 20 branches with diameters 3.05 to $5 \mathrm{~mm}$ (seldom grazed by cattle) and a minimum of 141 twigs with diameters $\leq 3 \mathrm{~mm}$. Leaf widths, lengths, and weight of leaf pairs were also recorded. Oven-dried weight parameters were regressed on oven-dried mid-internode diameter. Regression slopes and intercepts for the different sites were statstically compared $(p<0.05)$ using methods described by Snedecor and Cochran (1971).

Additionally, large branches on two moderately grazed areas near the Roosevelt site were sampled to determine the relationship between percent of twigs browsed and percent weight removed by grazing. The Horrell area is grazed year long and the Burnt Corral area was grazed 4 months prior to sampling. At each area 3 branches having a minimum of 10 twigs of current year's growth were sampled from each of 20 shrubs. Branches were oven-dried, numbers of grazed and ungrazed twigs were counted, and twig diameters were measured at the point of grazing for current and previous years' twigs. All remaining current and previous years' twigs with a mid-internode diameter $<3 \mathrm{~mm}$ were weighed. Weight removed by grazing was estimated using previously developed regression equations and divided by total weight to give an estimate of percent utilization by weight. Percent utilization by weight was regressed on percent browsed twigs and utilization estimates by number of browsed twigs and by diameter measurements were statistically compared $(p \leq 0.05)$ in a nested one-way analysis of variance. All twig diameters were measured to the nearest $0.05 \mathrm{~mm}$ with a dial caliper and weights were measured to the nearest $\mathrm{mg}$.

\section{Results and Discussion}

Twig weight components of jojoba were highly correlated with the square of oven-dried mid-internode diameter (Table 1, Fig. 1). Coefficients of determination $\left(r^{2}\right)$ were high when twig diameters between 3 and $5 \mathrm{~mm}$ were included in the analyses than when only

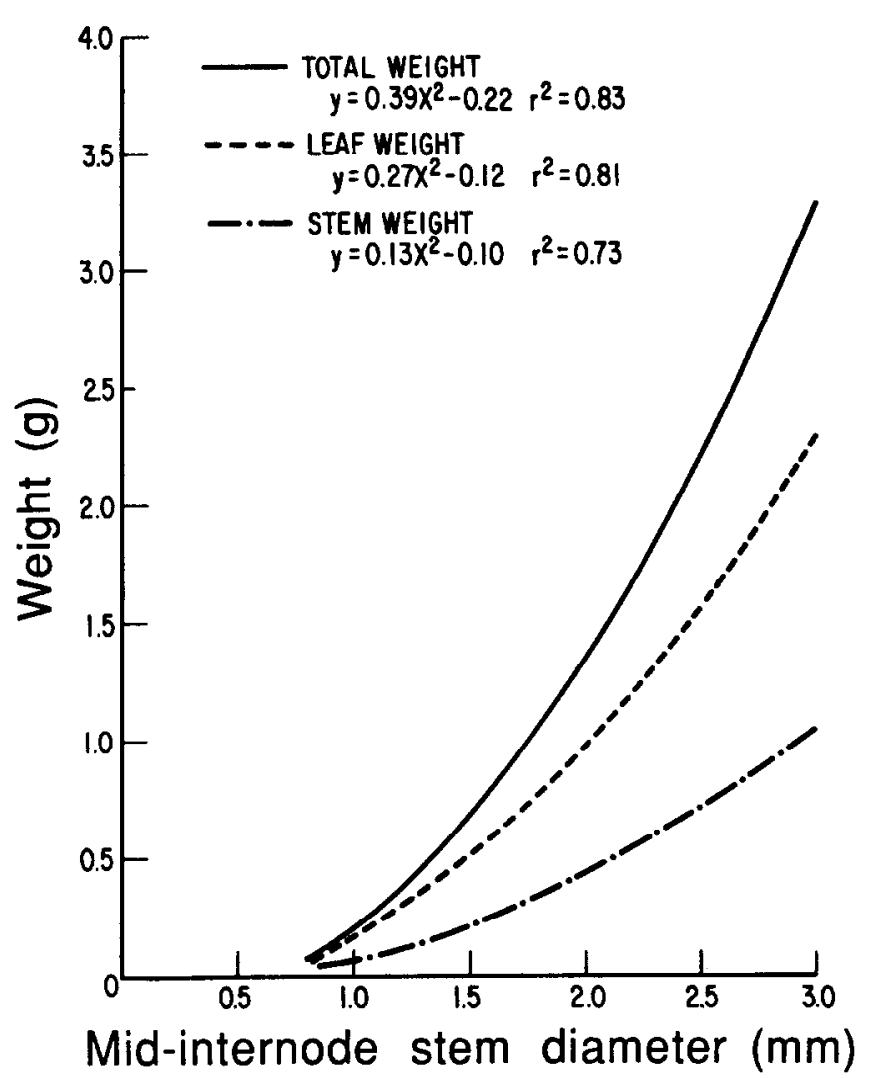

Fig. 1. Leaf, stem, and total oven-dried weight of jojoba twigs in relation to oven-dried mid-internode diameter for twigs with diameter $\leq 3 \mathrm{~mm}$.

twig diameters $\leq 3 \mathrm{~mm}$ were analyzed. Because of the larger sample size, the coefficients of determination are a better indication of twig weight variability with respect to mid-internode diameter for the smaller diameter twigs than the larger diameter twigs. Twigs $\geq 3$ mm diameter were rarely grazed so regressions for the smaller diameter twigs should be more useful in estimating utilization than those including the larger diameter branches. Regressions for the larger diameter branches indicate the potential of diameter-mass equations for estimating total biomass of jojoba.

Regression coefficients and intercepts had greater variation among sites when large diameters were included in the regression analysis than when only smaller diameters were analyzed (Table 1). Regression coefficients and intercepts of equations for estimating 


\section{HORRELL}

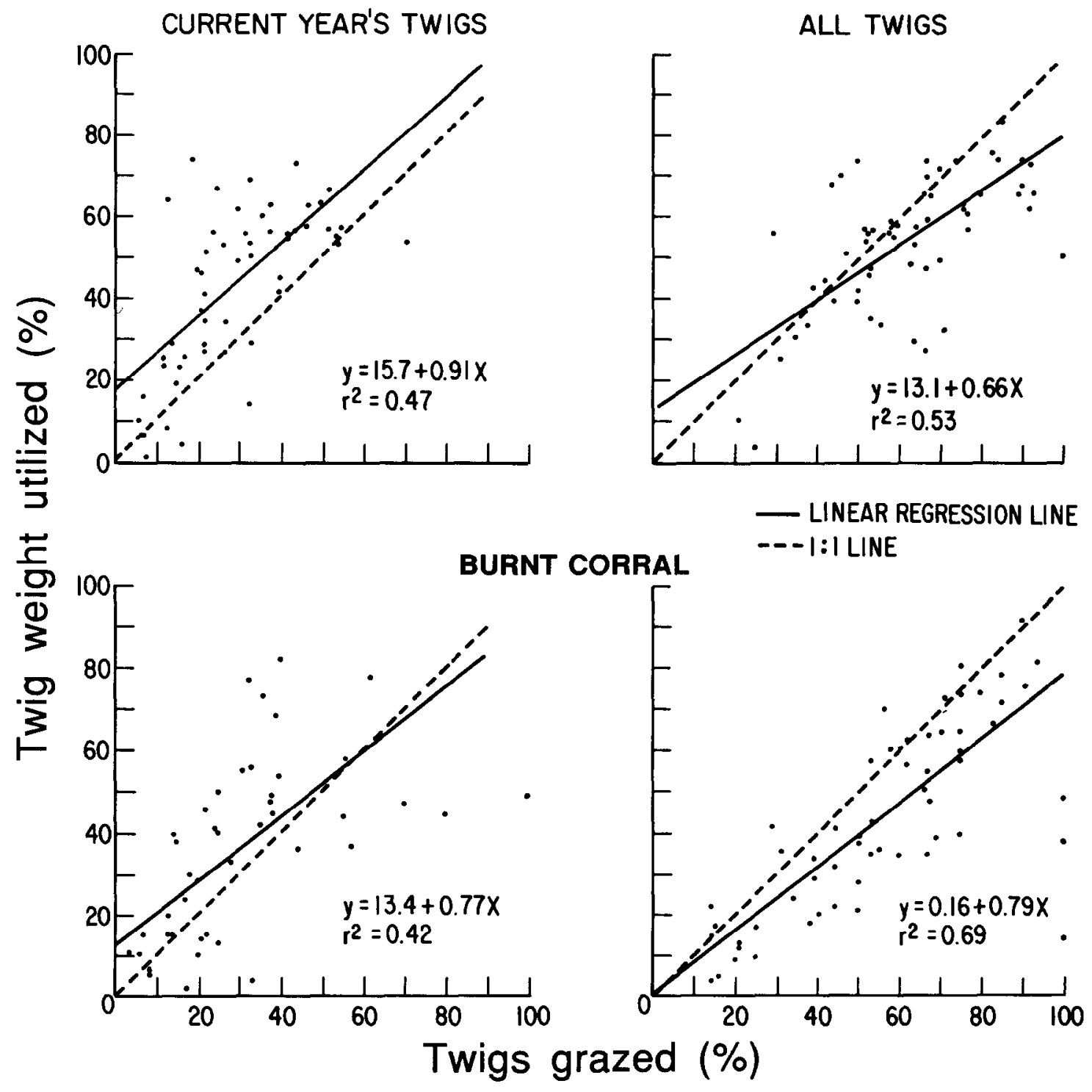

Fis. 2. Percent weight of jojoba utilized in relation to percent twigs browsed for moderately grazed shrubs at 2 areas in southern Arizona. All regressions are significant $(p \leq 0.05)$.

leaf weights varied more among sites than those estimating stem weights from small twig diameters.

Leaf weight accounted for an average of $73 \%$ of the total twig weight for small diameter twigs and was similar for all 3 sites. Mean leaf weights and size were also similar for all 3 sites (Table 2). Estimates of total twig weight for small diameter twigs varied less than $0.3 \mathrm{~g}$ among the 3 sites sampled. Equations for estimating total weight will be most useful in calculating jojoba utilization by cattle since they tend to browse both twigs and leaves of jojoba.

Table 2. Mean weights, lengths and widths of jojoba leaf pairs on 3 sites in southern Arizona.

\begin{tabular}{lcccc}
\hline \hline Site & $\begin{array}{c}\text { No. of } \\
\text { samples }\end{array}$ & $\begin{array}{c}\text { Leaf pair } \\
\text { weight }(\mathrm{mm})\end{array}$ & $\begin{array}{c}\text { Leaf length } \\
(\mathrm{mm})\end{array}$ & $\begin{array}{c}\text { Leaf width } \\
(\mathrm{mm})\end{array}$ \\
\hline Roosevelt & 153 & $159.7 \mathrm{a}$ & $23.8 \mathrm{~b}$ & $9.5 \mathrm{a}$ \\
Tucson & 141 & $137.2 \mathrm{a}$ & $23.0 \mathrm{~b}$ & $9.0 \mathrm{a}$ \\
Santa Catalina & 157 & $146.7 \mathrm{a}$ & $26.6 \mathrm{a}$ & $10.0 \mathrm{a}$ \\
\hline
\end{tabular}

Means in columns followed by the same letter have overlapping $95 \%$ confidence intervals.
There was a high correlation $\left(r^{2}=0.99\right)$ between fresh $(x)$ and oven-dried mid-internode diameter $(y)$ where:

$$
y(\mathrm{~mm})=0.922 x(\mathrm{~mm})-0.142
$$

The coefficients of determination of twig diameter and weight are not quite as high for jojoba on these sites as for many largeleafed eastern shrubs (Telfer 1969) or for western shrubs such as deerbrush (Ceanothus integerrimus) $\left(r^{2}=0.97\right.$, Bartolome and Kosco 1982); snowberry (Symphoricarpos oreophilus) $\left(r^{2}=0.90\right.$, Ruyle et al. 1983); blackbrush $\left(r^{2}=0.94\right.$, Provenza and Urness 1981); and bitterbrush (Purshia tridentata) $\left(r^{2}=0.89\right.$, Basile and Hutchings 1966). However, low standard errors of estimate (Table 1) indicate diameter measurements can give precise esimates of jojoba twig weight. Percent utilization can be determined by measuring maximum diameter of browsed and unbrowsed current year's twigs to determine total yield and by measuring diameters of browsed twigs at the point of browsing to determine weight removed by browsing. These measurements should be taken at the end of the grazing period before regrowth occurs. In developing and using diameter-weight relationships for jojoba it should be 
remembered that leaf fall may occur with summer drought (Gentry 1958). Also, flushes of vegetative growth associated with significant precipitation may occur in the spring and summer (Haase 1978). Jojoba utilization should be measured after significant growth and use periods.

Percentage of number of twigs browsed tended to be lower than percent utilization by weight for current year's twigs, but was slightly higher then weight utilization for total twigs on 2 moderately grazed areas (Fig. 2). Percent browsed twigs would tend to underestimate weight utilization of current year's twigs and overestimate utilization of total twigs, especially at high utilization levels. There was high variation in weight utilization among branches with similar percentages of twigs browsed. However, mean percent utilization by weight and by numbers of browsed stems was generally statistically similar for both areas. (Table 3). A plot of the

Table 3. Percent twigs browsed and percent weight utilized for moderatelygrazed jojoba on 2 areas in southerm Arizona.

\begin{tabular}{lccccc}
\hline \hline & \multicolumn{2}{c}{$\begin{array}{c}\text { Current years } \\
\text { twigs }\end{array}$} & & \multicolumn{2}{c}{$\begin{array}{c}\text { All twigs with } \\
\text { diameter } \leq 3 \mathrm{~mm}\end{array}$} \\
\cline { 2 - 3 } \cline { 5 - 6 } $\begin{array}{l}\text { Utilization } \\
\text { estimate }\end{array}$ & Horrell & Burnt Corral & & Horrell & Burnt Corral \\
\hline $\begin{array}{l}\text { Twigs browsed } \\
(\%)\end{array}$ & $27.2 \mathrm{~b}$ & $23.8 \mathrm{a}$ & & $59.1 \mathrm{a}$ & $54.8 \mathrm{a}$ \\
$\begin{array}{l}\text { Weight utilized } \\
(\%)\end{array}$ & $39.3 \mathrm{a}$ & $29.4 \mathrm{a}$ & & $52.0 \mathrm{a}$ & \\
\hline
\end{tabular}

Means in columns followed by the same letter are not significantly different $(p \leq 0.05)$.

variance of weight utilization in relation to sample size indicates at least 2 branch samples from each of at least 18 shrubs, with 10 or more twigs per branch, were needed to obtain a good estimate of utilization for those moderately grazed shrubs.

A major problem in estimating utilization of jojoba is that of determining how much current year's growth has actually been removed by grazing animals during a grazing period when some previous year's growth has been taken. It is not possible to determine how much current year's growth is associated with previous years' stems that have been removed in the current year. Cattle may graze some previous years' twigs in addition to current years' twigs.

Estimating yield and utilization from twig diameter measurements may be more accurate but is also more time-consuming than estimating utilization by counting numbers of browsed twigs. Management based on maintaining or gradually increasing shrub size relative to the potential for a given site may be a practical alternative to managing for a given level of utilization.

\section{Literature Cited}

Basile, J.V., and S.S. Hutchings. 1966. Twig diameter-length-weight relations of bitterbrush. J. Range Manage. 19:34-38.

Bartolome, J.W., and B.H. Kosco. 1982. Estimating browse production by deerbrush (Ceanothus integerrimus). J. Range Manage. 35:671-672.

Elias-Cesnick, A. 1982. Jojoba guide to the literature. Office of Arid Lands Studies, Univ. of Arizona, Tucson.
Garrison, G.A. 1971. Carbohydrate reserves and response to use. p. 271278. In: C.M. McKell, J.P. Blaisdell and J.R. Goodin (eds.) Wildland shrubs - their biology and utilization. USDA Forest Serv. Gen. Tech. Rep. INT-1. Intmtn. Forest and Range Exp. Sta., Ogden, Utah.

Gentry, H.S. 1958. The natural history of jojoba (Simmondsia chinensis) and its cultural aspects. Economic Botany 12:261-295.

Hanse, E.F. 1978. Phenology of some native jojoba populations in Arizona p. 39-47. In: Consejo Nacional de Ciencia y Tecnologia, la jojoba: Memorias de la II conferencia and internacional sobre la jojoba y su aprovechamiento. Ensenada, Baja California Norte, Mexico. Feb. 1976. Consejo Nacional de Ciencia y Tecnologia, Comision Nacional de las Zonas Aridas, Consejo Internacional sobre Jojoba, Mexico.

Jensen, C.H., and G.W. Scotter. 1977. A comparison of twig-length and browsed-twig methods of determining browse utilization. J. Range Manage. 30:64-67.

Judd, B.I. 1962. Principal forage plants of southwestern ranges. USDA Forest Serv. Rocky Mountain Forest and Range Exp. Sta., Sta. Paper 69. Fort Collins, Colo.

Kearney, T.H. and R.H. Peebles. 1964. Arizona flora. Univ. of California Press, Los Angeles.

Knipe, T. 1956. The javelina in Arizona. A research and management study. Arizona Game and Fish Dep., Phoenix, Wildlife Bull. 2.

Martin, A.C., H.S. Zim, and A.L. Nelson. 1951. American wildlife and plants. A guide to wildlife food habits: The use of trees, shrubs, weeds and herbs by birds and mammals of the United States. McGraw-Hill Book Company, New York.

MeCulloch, C.V, and P.J. Urness. 1973. Deer nutrition in Arizona chaparral and desert habitats. Arizona Game and Fish Department, Research Division, USDA Forest Serv. Rocky Mountain Forest and Range Exp. Sta. Special Report 3.

Provenza, F.D., and P.J. Urneas. 1981. Diameter-length-weight relations for blackbrush (Coleogyne ramosissima) branches. J. Range Manage. 34:215-217.

Russo, J.P. 1956. The desert bighorn sheep in Arizona: A research and management study. Wildl. Bull. 1. Arizona Game and Fish Dep., Phoenix.

Rutherford, M.C. 1979. Plant-based techniques for determining available browse and browse utilization. Bot. Rev. 45:203-208.

Ruyle, G.B., J.E. Bowns, and A.F. Schlundt. 1983. Estimating snowberry (Symphoricarpos oreophilus) utilization by sheep from diameter-weight relations. J. Range Manage. 36:472-474.

Scarlett, P.L. 1978. Jojoba in a nutshell. Jojoba International Corporation. Carpinteria, California.

Sherbrooke, W.C. 1976. Differential acceptance of toxic jojoba seed (Simmondsia chinensis) by 4 Sonoran Desert heteromyid rodents. Ecology 57:596-602.

Snedecor, G.W., and W.G. Cochran. 1971. Statistical methods. Iowa State Univ. Press. Ames.

Stickney, P.F. 1966. Browse utilization based on percentage of twig numbers browsed. J. Wildl. Manage. 30:204-206.

Tolfer, E.S. 1969. Twig weight-diameter relationships for browse species. J. Wildl. Manage. 33:917-921.

Thomson, P.H. (ed.). 1976. California rare fruit growers jojoba handbook. California Rare Fruit Growers Spec. Pub. 2., Star Route Box P. Bonsall, Calif.

Urness, P.J., A.D. Smith, and R.K. Watkins. 1977. Comparison of in vivo and in vitro dry matter digestibility of mule deer forages. J. Range Manage. 30:119-121.

USDA Foreat Service. 1979. Allotment analysis handbook. Southwestern Region 3. Albuquerque, N. Mex. 